\title{
Art Imitating War? Observe the Sons of Ulster Marching Towards the Somme and its Place in History
}

Jacqueline Hill

\section{(2) OpenEdition \\ Journals}

\section{Electronic version}

URL: http://journals.openedition.org/etudesirlandaises/1084

DOI: 10.4000 /etudesirlandaises. 1084

ISSN: 2259-8863

\section{Publisher}

Presses universitaires de Rennes

\section{Printed version}

Date of publication: 30 June 2009

Number of pages: $37-52$

ISBN: 978-2-7535-0935-1

ISSN: 0183-973X

\section{Electronic reference}

Jacqueline Hill, « Art Imitating War? Observe the Sons of Ulster Marching Towards the Somme and its Place in History », Études irlandaises [Online], 34.1 | 2009, Online since 30 June 2011, connection on 01 May 2019. URL : http://journals.openedition.org/etudesirlandaises/1084 ; DOI : 10.4000/ etudesirlandaises. 1084

This text was automatically generated on 1 May 2019.

(C) Presses universitaires de Rennes 


\title{
Art Imitating War? Observe the Sons of Ulster Marching Towards the Somme and its Place in History
}

\author{
Jacqueline Hill
}

1 Observe the Sons of Ulster Marching Towards the Somme (henceforth OSU), by Frank McGuinness, is among the foremost Irish history plays of the twentieth century. First performed in Dublin in 1985, it is the play that first won the author international acclaim, and after Someone Who'll Watch Over Me (1992) it is his most frequently staged play. From the outset, it was hailed as a major dramatic work, exploring ways in which the historical past could both galvanise and yet shackle the imagination ${ }^{1}$.

2 The play's main character, Kenneth Pyper, is a survivor of the battle of the Somme in July 1916, who looks back on the war-time experiences of his immediate group of fellowProtestant combatants, members of the 36th (Ulster) Division. They all joined up at the start of the Great War in 1914 and (with the exception of Pyper) all lost their lives at the Somme. As an old man living in Ulster, the elder Pyper recalls the events of the Great War through the prism of "the Troubles"; but virtually all the action in the play is set in the period from the men's first enlisting to its climax at the Somme. Given the play's subject matter, it has attracted some comment from historians ${ }^{2}$, but there has been no sustained examination of its place in the evolving historiographical tradition of the First World War. This article sets out to fill that gap.

The play does not, of course, set out to be a work of history, and it is argued here that while the matter of whether it "got the details right" - such as whether the combatants might plausibly have donned Orange sashes before going into battle on $1 \mathrm{July}$, or shouted "No Surrender!" as they went over the top - is important, the play raises wider issues to be explored. These include the question of who enlisted and why; why, despite growing evidence of casualties on an unprecedented scale, the combatants were prepared to stay and fight; Ulster Protestant identity and the First World War, and the wider issue of 
history and memory. The views of historians from the time of the Great War onwards will be examined to assess how the play stands up in the light of these issues.

It used to be remarked that Irish historians had been particularly slow in getting to grips with twentieth-century history ${ }^{3}$. Even outside Ireland, however, in respect of the First World War, the early interest shown by historians remained for many years highly selective, focusing mainly on the war's origins. This was driven, understandably, by the desire to avert future conflict, and by the perceived need to confirm, deny, or transcend the issue of "war guilt". Debate about the war's origins continued after the Second World War, peaking in the $1960 \mathrm{~s}^{4}$.

5 Meanwhile, all over the world survivors of the conflict, and the millions of the bereaved, had perforce to try to come to terms with their losses, both individually and collectively. Publishers were not slow to try to cater for this potentially huge market. On the Allied side - to pick an example at random - in 1919 the publishers of Punch brought out what they called Mr Punch's History of the Great War, a compendium of articles and cartoons that had appeared in the magazine during the conflict. Military memoirs also appeared, and, within a decade of the Armistice, collections of soldiers' letters from the front had been published in Germany ${ }^{5}$.

6 Although the Punch history did not lack the customary elements of humour and the ridiculous, the overall thrust of such early works was, for the most part, highly partisan, and stressed the heroism, patriotism, and fighting spirit of the combatants. However, when a collection of British soldiers' letters was published in 1930, its tendency was rather different. The editor, Laurence Housman, was a socialist and pacifist who hoped to expose the horrors of war, and the collection was published by the Left Book Club ${ }^{6}$. A similar questioning of the meaning of the war, notably in countries that had been on the victorious side, was already underway in the literary sphere, by poets, novelists, dramatists and film-makers; while in the social sciences some of the ground work was laid for the study of what some later scholars would call "social memory".

7 An important stimulus for research in this field was a study by a Professor of English that drew heavily on British literary evidence and soldiers' memoirs, Paul Fussell's The Great War and Modern Memory (1975), a work whose influence on OSU Frank McGuinness has acknowledged $^{8}$. Fussell contended that a pre-war world in which everyone knew the meaning of honour, glory and Christian sacrifice had been shattered by the war, and especially by the experience of the Somme. On the first day of infantry deployment (1 July 1916) the British army alone suffered some 60,000 casualties: the combined British and French casualties over the entire six-month duration of the Somme campaign were ten times that number, without producing any significant gains ${ }^{9}$. The dashing of hopes and expectations on such a scale fostered in certain writers a sense of disenchantment, detachment, and irony, attitudes that for Fussell came to represent the dominant, "essentially ironic", form of modern understanding ${ }^{10}$. Fussell's conclusions proved controversial ${ }^{11}$, but helped to encourage historical research. By the 1990s the study of "history and memory" had become a major field for historical research in its own right: this was not confined to the subject of the First World War, but that event did figure largely in the genre ${ }^{12}$.

8 As far as Irish historians were concerned, in the decades immediately following the war there was little incentive to join in the international discussion about its origins. On both sides of the newly instituted border (1920) between Northern Ireland and the Irish Free State there was a concern with internal matters; moreover, the writing of contemporary 
history was not encouraged by the journal Irish Historical Studies (1938-) dedicated to "the scientific study of Irish history ${ }^{13}$ ".

9 None of this, however, prevented the appearance of publications on Irish participation in the war, with early contributions falling into the "heroic" camp ${ }^{14}$. The main account of the 36th (Ulster) Division was by Cyril Falls, who had been a captain in the Royal Inniskilling Fusiliers. Falls (who in the 1940s became Chicele Professor of the History of War at the University of Oxford) drew not only on official records but on contributions sent by many who had served with the Division. He emphasised that he had attempted to present life as lived during the war, moving beyond a mere record of battles ${ }^{15}$, but the book was first and foremost a military history intended as a tribute to those who had been killed in the war, and to those who had returned.

However, such works inevitably bore an added significance, appearing as they did during the crucial years that saw the formation of the new Northern Ireland. The 36th Division had been overwhelmingly Protestant and Unionist in its composition. The Somme was its first major engagement, and on 1-2 July 1916 its members had succeeded in penetrating further into German lines than any other unit: four V.C.s were subsequently awarded to individual members for heroism. But their success had been negated by poor support and the rigidity of the British battle plans - admitted by Falls, though he also claimed that the battle "laid the foundations of future victory ${ }^{16}$ " - and the Division had suffered very heavy casualties ${ }^{17}$. Yet it continued to have an impressive record for the remainder of the war. It is clear that there was a sense among Ulster Unionists that a record of the Division's achievements would not alone memorialise the dead and comfort the bereaved but also reinforce and justify their own claim to special treatment in the settlement of the Home Rule issue. At all events, Falls' book was commissioned by a high-powered committee, and a fund set up to cover the costs of production. Within weeks it was "largely oversubscribed". Among the patrons were Lord (formerly Sir Edward) Carson of Duncairn and Sir James Craig, Prime Minister of Northern Ireland ${ }^{18}$. Accordingly, without containing an explicit contemporary political message, Falls' book was a celebration of "the men of Ulster". Their discipline, gallantry and spirit of self-sacrifice had depended only in part on their military training: the other element was "a racial spirit possessing already in amplitude the seeds of endurance and of valour ${ }^{19}$ ". Not surprisingly, in view of the fact that 1 July (Old Style: before the calendar reform of 1752) had been the date of the Battle of the Boyne (1690), the commemoration of the Somme was added to the anniversary calendar of the Orange Order ${ }^{20}$.

11 For many years, there were few challenges in Northern Ireland to the "heroic" interpretation of the war ${ }^{21}$. Echoing their predecessors, historians noted that for Ulster Protestants the Somme bore much the same significance as the 1916 Easter Rising against British rule did for Catholics: a blood sacrifice, "a pledge of burning sincerity ${ }^{22}$ ". The fiftieth anniversary of the battle, which coincided with the anniversary of the Easter Rising, did not, as in the latter case, give rise to a crop of new books on the subject. However, it did see the publication of a new, non-partisan, overview of the role of all the Irish regiments in the war, aimed in part at reminding southerners and Catholics of their own contribution ${ }^{23}$. The anniversary also prompted some reflections by veterans that questioned the quality of military leadership ${ }^{24}$. The onset of "the Troubles" in the late 1960s prompted a greater interest, particularly in the Irish Republic, in the circumstances of the setting up of Northern Ireland. Certain historians gave the war a socialist gloss, arguing that the tradition of the Somme was of interest only to the ascendancy class: "the 
European war was fought for no cause of the poor Protestants of Sandy Row or the Shankill Road ${ }^{25}$..."

12 The pace of change in Northern Ireland from 1968 to 1972 under the stimulus of "the Troubles", coming as it did so soon after what amounted to rapid British disengagement from the African empire during the early 1960s, naturally encouraged speculation as to whether the British government would or should disengage from Northern Ireland ${ }^{26}$. For some, such a course of action was regarded as a panacea for the Northern problems. However, over the next decade, during which violence on both sides continued to claim lives, and the loyalist Ulster Workers' Council defied the government with its general strike and helped to bring down the Sunningdale assembly, it became clear that the problem was more intractable. Among some Unionists, "the Troubles", far from inducing a spirit of cooperation with nationalists or republicans, prompted a new emphasis on the uniqueness of Ulster identity ${ }^{27}$, thus signalling not merely to Dublin but also to London that Northern Ireland Protestants were as likely to insist on their right to selfgovernment as to cast in their lot with the Republic.

Against this background, new surveys appeared from historians with a long-standing interest in Ulster history which sought to analyse the causes of this apparent intractability. One such survey, The Narrow Ground, by A. T. Q. Stewart, is worth dwelling on because McGuinness has acknowledged that it was one of the historical works he read when preparing to write the play ${ }^{28}$. Stewart argued that there existed in Northern Ireland historic patterns of behaviour and attitude that tended to come into operation at times of crisis. It was sometimes supposed, he contended, that such atavistic patterns themselves constituted the nub of the problem; but that was not the case. The onset of "the Troubles" in the late 1960s owed more to events in Paris in 1968 than to the penal laws or the Battle of the Boyne. Stewart's point was that once contemporary pressures had come into operation, then "the form and course of the conflict are determined by patterns concealed in the past, rather than by those visible in the present". Given the inability of the authorities to contain the violence of the 1970s, the civil population on both sides had turned to "the ancestral voices", "the inherited folk memories of what had been done in the past". In other words, quoting Kipling, "the Gods of the Copybook Headings in fire and slaughter return ${ }^{29}$ ".

If OSU owes a debt to The Narrow Ground, most obviously expressed in Pyper's often tortured engagement with his own "ancestral voices", the "Protestant Gods" ${ }^{30}$, other debts are also apparent. McGuinness has indicated that his interest in the war was originally awakened by Jennifer Johnston's novel How Many Miles to Babylon? (1974), which deals with Irish Catholic participation in the war. Subsequently, it was the war memorial in Coleraine, County Londonderry, with its lists of the names of the dead, which prompted a curiosity about the significance of the Somme for Ulster Protestants. This was a topic about which McGuinness's own education as a Catholic in Buncrana, County Donegal (in the Irish Republic) had furnished few insights ${ }^{31}$. Fussell's treatment offered a precedent for placing the infantry at the heart of the "drama", a metaphor so frequently used by contemporaries when describing the war ${ }^{32}$. For Fussell, the lowest ranks of fighting men represented the very embodiment of the blasted hopes and lost innocence which for him was the hallmark of the war and particularly of the Somme for British troops at the western front. He pictured them as isolated from their officers (by class and military hierarchies); from the enemy (who in conditions of trench warfare were frequently invisible); and of course from their friends and relatives at home (less by 
geographical distance than by the nature of their experiences on the front) ${ }^{33}$. These are conditions which also obtain in OSU.

However, while Fussell was preoccupied with the generality of experience of daily life at the front ${ }^{34}, \mathrm{OSU}$ is concerned with the particular experience of eight fictional Ulstermen, all (with one doubtful exception) Protestants, as the survivor Pyper remembers them. When the play was first performed, it was remarkable to see such a subject represented on a Dublin stage. As noted above, the interest shown by historians and others during the 1970s in the history of Northern Ireland had been driven by a desire to understand "the Troubles" and (apart from Harris's pioneering study) had not involved any systematic consideration of the significance of the First World War or the Somme. Since then, mainly under the impetus of the "history and memory" school in which the First World War has played so prominent a part, a great deal has been written about the war, both from an Irish and an international perspective ${ }^{35}$. How does OSU stand up in the light of this new research?

One major area of interest for Irish historians has been the question of who enlisted to fight in the war. Since conscription was never applied to Ireland, the recruits were all volunteers, and their composition has now been comprehensively analysed. The findings have confirmed that Ulster consistently provided the highest ratio of enlistment of the four Irish provinces: just over half of all Irish enlistments came from Ulster ${ }^{36}$. However, recruitment from Ireland in general began to decline as early as mid-1915; Ulster recruitment held up better, but the number of battalions to be supplied was higher, and by the autumn of 1916 there were serious manpower shortages across all the Irish regiments ${ }^{37}$. As for the 36th (Ulster) Division, its overwhelmingly Protestant nature has been confirmed; Catholics were discouraged from joining it, and their numbers were very small ${ }^{38}$. Thus far, the findings are consistent with the picture presented of the 36th Division in OSU, which features only one quasi-Catholic, Martin Crawford from Derry town, who privately divulges to Christopher Roulston that he may have been baptised a Catholic ${ }^{39}$. However, any idea that Irish enlistment in general was a mainly Protestant phenomenon has been demolished. Less than half - about 43 per cent - of all Irish recruits from 1914 to 1918 were Protestants; and the initially high recruitment levels in Ulster were reflected among nationalists as well as loyalists ${ }^{40}$.

Why did Ulster Protestants enlist? For Falls the answer had been simple: they believed in their leaders as well as in themselves, and their leaders urged them to come forward for the defence of the Empire, the honour of Ulster, and of Ireland ${ }^{41}$. And in OSU too the new recruits, when asked directly why they have enlisted, tend to speak in similar terms except for Pyper, who has his own complex reasons for joining. However, it takes little reading between the lines of either Falls' account or OSU to suspect that the reality was more complex, and it is the non-rhetorical aspects that have recently been engaging historians' attention. Data from official sources shows that the propensity to enlist was affected by social and economic conditions ${ }^{42}$, but that did not mean that men joined up simply to escape unemployment, as James Connolly suggested ${ }^{43}$. In fact, there was disproportionately heavy enlistment from such stable trades as engineering and shipbuilding, perhaps because it could be taken for granted that there would still be plenty of work in such trades when the war ended. In the countryside, there was marked reluctance to enlist among farmers' sons and farm workers; and taken overall, recruitment was much lower in rural than in urban areas. It should be noted, too, that 
there was some alienation of Ulster Unionists from government in the summer of 1914 because of the passing of the Home Rule Bill, which may have affected recruiting ${ }^{44}$.

No doubt, as some survivors later suggested in a deliberate debunking exercise, for many recruits it was simply a matter of wanting to escape the monotony of life at home: war offered the prospect of novelty and adventure ${ }^{45}$. However, there was one factor that stands out above all as influencing participation. The intense militarism of the climate on the eve of the war (which affected nationalists as well as unionists) meant that military life was held in esteem; and the idea that war was "natural" - drawing on Darwinian assumptions - was gaining ground. Heroic qualities were there to be realised, both on an individual level and as part of a team ${ }^{46}$. Before the war large numbers of Protestants belonged to the Ulster Volunteer Force, formed to resist Home Rule, while many Catholics belonged to the rival Irish Volunteers. In total, these private armies contained over 250,000 men, and when war broke out both Sir Edward Carson for the Ulster Volunteers and John Redmond for the Irish Volunteers expected that their own force would be embodied as a Division. Carson's wish was quickly granted, but it took another month to authorise a "second new army", of which the 16th (Irish) Division was to be part. Overall, it has been calculated that of the Ulster recruits in the early months of war, over fourfifths of Protestants and the same proportion of Catholics had belonged to their respective private army ${ }^{47}$.

Membership of the Ulster/Irish Volunteers was thus the most important of the group or collective pressures that encouraged recruitment. Precisely how such pressures influenced the enlistment of individuals awaits fuller study of personal records, but research so far highlights the attitudes of comrades in pre-existing small units ${ }^{48}$, and decisions made by kinsmen, neighbours and fellow-members of associations such as sporting clubs and fraternities, among them the Ancient Order of Hibernians, the Orange Order, and Masonic lodges ${ }^{49}$. Local connections in general appear to have been particularly important - this was not merely an Ulster phenomenon, but found in Britain too. Such connections were reflected in the names of various battalions of the $36^{\text {th }}$ Division: "East Belfast Volunteers", "South Belfast Volunteers", "South Antrim Volunteers", and so on ${ }^{50}$.

In the context of these findings, the characters in OSU are not unrepresentative of Ulster Protestant recruits. Several of them, certainly Moore, Millen and Craig, had been active in the Ulster Volunteers; Anderson and McIlwaine were shipyard workers. For the purposes of the play, it is necessary that some characters should have joined up as individuals, but Moore and Millen, Anderson and McIlwaine were comrades or colleagues before enlisting. Given that the war was not "over by Christmas", as many had expected, but had already cost hundreds of thousands of lives by the end of 1914 alone ${ }^{51}$, historians have also begun to ask, why did the men stay? of course, fear of official reprisals against deserters, or "cowards" was one explanation: in OSU Millen is warned by McIlwaine that merely criticising officers could lead to a court martial. Recent research shows that the number of men tried by courts martial for a variety of disciplinary offences was higher in Irish regiments than in English, Scottish and Welsh ones; however, Irish soldiers were not over-represented among those executed following courts martial ${ }^{52}$.

In any case, fear of reprisals was hardly a sufficient explanation for willingness to stay and fight. Fussell's study in 1975 highlighted the "innocence" of the troops, their elevated language of personal control and honour, and also their sense of confidence: on the eve of the Somme even the generals felt that God was on their side ${ }^{53}$. Recent research has 
offered a somewhat modified view. Confidence there was, in the effects of British artillery in preparing the way for the advance of the infantry, and although this turned out to be misplaced at the Somme, in the longer term improvements in artillery meant that the war came to an end on Allied terms ${ }^{54}$. Morale-boosting initiatives were common: the 36th Division possessed a concert troupe and cinema. Group loyalty - often loyalty to very small groups - was an important factor. Jay Winter has noted that such camaraderie made the war a very private affair indeed, with survival chances often depending on two or three men. Such bonds, frequently pre-dating the war, were reinforced by the isolation of platoons at the front ${ }^{55}$. All this is prefigured in OSU through the creation or intensification of relationships ("pairing and bonding"), the results of which are recalled by the elder Pyper as the play begins. He remembers Anderson's vain attempts to save his friend McIlwaine; and Moore endlessly searching for Millen, supposed dead ${ }^{56}$. In such conditions homo-erotic relationships might develop: in OSU that between Pyper and Craig even comes to win a certain acceptance from the other characters ${ }^{57}$.

The role of the junior officers, who (in contrast to the "top brass") served in the trenches alongside the men, has also been stressed. Overlooked in Fussell's account, and largely absent from OSU (one is said to have passed through the trench shortly before the battle is due to begin, only to be dismissed by Millen as a "useless bugger"), these officers in fact shared the risks of the men they led, and their death rate was even higher: 20 per cent as compared with 10-12 per cent of enlisted men in combat units ${ }^{58}$. Desertion, or failure to return after leave, meant breaking faith with such officers. All this casts doubt on the (mainly recent) perception of the infantry as mere victims, duped into sacrificing themselves by remote and unfeeling officers. The quality of British high command at the Somme, so long regarded as lamentably poor, has also come in for some reassessment ${ }^{59}$.

Additional resources to sustain morale at the front were also available. All accounts mention the importance of religion, and those of the 36th Division emphasise that the reading of bibles was particularly common among Ulstermen ${ }^{60}$. This must have eased the task of the Young Men's Christian Association (YMCA), which provided (in addition to a canteens system) religious, educational and social activities among the men. The work of the Y.M.C.A. in the 36th Division was highly praised by Major General Powell ${ }^{61}$. OSU strikes a sceptical note in having Moore draw attention to profane uses of the bible, but as the battle approaches, he and his comrades find more conventional comfort in hymn singing and prayer ${ }^{62}$.

The significance of the Orange tradition, on the other hand, has become a matter of some controversy, which in respect of OSU has centred on the donning of Orange sashes by the men as they prepare to fight on $1 \mathrm{July}^{63}$. A number of points can be made. That membership of the Orange Order, although it has not been quantified, was present in the 36th Division seems certain; several battalions in the Division had their own Orange lodges, and lodge meetings took place at the front ${ }^{64}$. In July 1915 , the War Office went so far as to move the 36th Division from Ireland to Britain lest men desert to participate in Orange parades on 12 July ${ }^{65}$. None of this, of course, meant that membership of the Order was the norm in the Division. As to the invoking of Orange symbols on the first day of the battle (the old Style anniversary of the battle of the Boyne) there are conflicting reports. Several early accounts indicated that the men were aware of, indeed inspired by, the significance of the date ${ }^{66}$. The source for shouts of "No Surrender" as the men went over the top has been traced to a letter from an English officer at the front to the Belfast Grand Master of Orange Lodges, which was published in the press on 7 July $1916^{67}$. Among the 
veterans he studied, Philip Orr found some contemporary evidence for the wearing of Orange lilies, and the singing/whistling of Orange songs. Certainly, the Orange Order was quick to incorporate symbols associated with the Somme into their banners ${ }^{68}$.

However, a survivor who wrote to the Belfast Telegraph in 1966 criticised the "nonsense stuck on to the story". Admittedly, an orange handkerchief had been waved, but orange was his battalion's colour; and the writer cast doubt on the extent to which the significance of 1 July was widely known ${ }^{69}$. Doubt on the wearing of sashes was expressed by the survivor cited by Kevin Myers ${ }^{70}$. Keith Jeffery's verdict seems judicious: "reliable authority for these stories is hard to come by, and they have certainly multiplied in the telling ${ }^{71}$." But ultimately, given the presence of Orangeism in the Division, the donning of the Orange sashes is not intrinsically implausible, and it makes sense in terms of the action of the play, symbolising as it does not merely the men's commitment to each other, but Pyper's acceptance of himself as one of them and his reconciliation with his “ancestral voices".

These matters lead naturally on to the issue of "history and memory". The twentieth century, with its questioning of the integrity of the self, of authorship, and the reliability of human memory, prompted scepticism in some quarters about the extent to which the past is knowable at all. The inherent subjectivity of even eye-witness reports has become more widely recognised, and the passage of time raises even more questions about the "authenticity" of what is recalled ${ }^{72}$.

Such issues lie at the very heart of OSU, since so much of what happens on stage is a function of the memory of the elder Pyper. At the outset Pyper makes the disclaimer: "I am not your military historian", which at its simplest reminds the audience of the subjectivity of his testimony, but also raises the possibility that his interpretation of his group's wartime experience may be influenced - and almost certainly is influenced - by later events, and specifically, it appears, by "the Troubles", to which he alludes. The warning is compounded by Pyper's statement that "I am a liar "7". In fact, we take on trust what he tells us of the group, because the men he recalls are so vividly brought to life ${ }^{74}$.

Where, then, does OSU fit into what historians have had to say about Ulster Protestant identity and the First World War? Of course, it was neither the war nor the Somme that induced northern Protestants to highlight their "Ulster" identity, which in its modern form can be traced back to the first Home Rule crisis in 1886, and indeed further back still ${ }^{75}$. However, not only did contemporary considerations influence the appearance of early tributes to the 36th (Ulster) Division such as that of Falls, but they also coloured the process of commemoration. Given the evidence, now available in some detail ${ }^{76}$, about Catholic participation in the war - including the battle of the Somme, though mostly in its later stages - there was no inherent reason why in Northern Ireland the war should not have been commemorated in ways that would have been inclusive of the two communities.

30 That this (though there were exceptions) did not happen, and the process of commemoration became "overwhelmingly an opportunity to confirm loyalty to the British link and affirm Ulster's Protestant heritage 77 ", has to be evaluated in the light of the circumstances in which Northern Ireland was set up. The campaign waged by the IRA in Northern Ireland in 1921 and 1922, endorsed by the hawkish element in the provisional government in Dublin, was intended to destabilise the province and force an end to partition. This served to reinforce and intensify the traditional Protestant sense of siege, and put a premium on ensuring Unionist unity ${ }^{78}$. Meanwhile, in the Irish Free State the 
tradition of commemorating the war, quite strong in the immediate post-war decades, was dealt a blow by Irish neutrality in the Second World War: such commemoration, it was feared, could imply support for the new British war effort ${ }^{79}$.

By the time Unionists faced their next major challenge with the onset of "the Troubles" nearly half a century later (the background against which the elder Pyper recalls his wartime experience), much had changed. What has been called their "multi-layered" sense of identity, comprising Ulster, Irish and British imperial elements, was becoming more problematic ${ }^{80}$. Although by the 1920 s Unionists had come to accept devolution for the North, their sense of Irishness, already diminishing in the period of the Home Rule crisis, had been further eroded by the Gaelicising policies and de facto status accorded to the Catholic church in the Free State, and by the different experiences, on either side of the border, of the Second World War and its aftermath. Identification with Britain, which had drawn much of its strength from ties of religion and common imperial interests, became less straightforward as the influence of mainstream Protestant churches diminished in Britain and disengagement from empire gathered pace. The advent of the Cold War reduced Northern Ireland's strategic importance, as did the accession of Britain and the Irish Republic to the EEC. Thus the abolition of the Stormont parliament in 1973, which dramatically demonstrated the limits of self-government, was followed by greater interest, in some loyalist and Unionist quarters, in the idea of an autonomous Northern Ireland ${ }^{81}$. The Protestant tradition of self-reliance could be invoked, which provides a context in which the elder Pyper could appropriate the meaning of "Sinn Féin" ("Ourselves alone") for Ulster Protestants ${ }^{82}$. And if there were sectarian and atavistic overtones in such a response, there were also positive elements, including love of place and landscape: both aspects are reflected in OSU ${ }^{83}$.

The first production of OSU in 1985 generated considerable controversy in Ireland. Theatre critic David Nowlan may have exaggerated when he called the play "one of the most devastating attacks ever made on Ulster Protestantism" ${ }^{84}$, but it can be read as an indictment of the traditional values of loyalty to king, creed, and empire that rendered men willing to sacrifice their lives at the behest of faceless and incompetent "top brass". The power of these traditions is dramatically brought to life by the men's action in donning their Orange sashes, and in the consent of Pyper - who had mocked those traditions - to join in that symbolic act. The hymn they all sing is redolent of the ultimate sacrifice they are about to make: "I'm but a stranger here, Heaven is my home" ${ }^{85}$. That such values are represented in the play as having enduring power, reaching into the late twentieth century, can be seen as rendering them all the more malign and destructive. We observe that in later life Pyper still clings to these values, despite the fact that they may seem to be ineffective or, indeed, counterproductive: "the house has grown cold. Ulster has grown lonely ${ }^{86}$." To this extent, the play is consistent with the twentiethcentury "modernist" rejection of traditional "heroic" interpretations of the war, informed as the latter were by high-flown sentiments and patriotic certainties ${ }^{87}$.

However, such a verdict on the play is not sufficient. For the play, at another level, is also about Pyper's mourning for his comrades. If he adopts their values, if he returns home to Armagh, it appears that he does so willingly as an affirmation of love for them and for Ulster. Certainly, any dreams he may have had about a future life with Craig were blasted by the war, but nevertheless his wartime experiences were the richest and most intense of his life ${ }^{88}$. Even in old age he is still visited by the men's ghosts, and struggles to make sense of their deaths, at one moment blaming God, at another accepting that this is too 
simple: "in the end, we were not led, we led ourselves ${ }^{89}$." To this extent, the elder Pyper represents not just one Ulster Protestant but millions of survivors, who were faced, like him, with the task of finding meaning in such appalling losses.

In their study of commemoration, historians have noted that it was generally the case, not merely in Britain and Ireland, that its forms and processes owed much to traditional values, to religious and patriotic symbolism, to romantic and classical styles that had been prevalent in the nineteenth century and even earlier. Certainly, even before the war ended, there were those who rejected a patriotic and religious response; but the point has been made that the modernist critique, with its emphasis on dislocation, paradox, and irony, lacked the power of traditional forms and images to mediate bereavement ${ }^{90}$. Hence the propensity to commemorate the dead with crosses and cenotaphs, obelisks and war memorials containing their "Rolls of Honour". These memorials became the focus for anniversary gatherings. Such invocation of the dead, Winter has argued, transcended class and rank and created "a bond of bereavement ${ }^{91 "}$.

Tradition, in other words, provided a cathartic language of mourning, both at a private and a collective level, something that was not unique to Ulster, or to Ulster Protestants. This was less obviously the case after the Second World War, which threw up horrors unmatched even in the First, and was not followed, or not to the same extent, by the revival of traditional forms of language and imagery: silence sometimes seemed the only appropriate response. It was after that war, it has been argued, that the modernist critique took hold more strongly ${ }^{92}$, and it is from this later world that the elder Pyper addresses us, when the search for meaning had become much more difficult. Appropriately, at first, it seems, he will be unable or unwilling to describe his experience, but he brings himself to do so. Not the least of his achievements in this play is that in OSU McGuinness overcomes the temptation simply to imprison his characters at one end of the spectrum of twentieth-century responses to the meaning of two world wars.

I am grateful to Keith Jeffery for reading this article and for his helpful suggestions. Errors that remain are, of course, my own.

\section{NOTES}

1. OSU was awarded the Dan Rooney Prize for Literature in 1985, and the Christopher Ewart-Biggs Memorial Prize in 1987. For an illuminating interdisciplinary study of the play see Bernhard Klein, On the Uses of History in Recent Irish Writing, Manchester, Manchester University Press, 2007, pp. 101-24; see also Claire Gleitman, "Reconstructing History in the Irish History Play", in Shaun Richards (ed.), The Cambridge Companion to Twentieth-Century Irish Drama, Cambridge, Cambridge University Press, 2004, p. 218-30, and Eamonn Jordan, The Feast of Famine: The Plays of Frank McGuinness, Bern, Peter Lang, 1997, p. 25-45.

2. See, e.g., Keith Jeffery, "Under the Blood-Red Hand", Times Literary Supplement, No. 4312, 22 Nov. 1985, p.1326; Joep Leerssen, "Monument and Trauma: Varieties of 
Remembrance", in Ian McBride (ed.), History and Memory in Modern Ireland, Cambridge, Cambridge University Press, 2001, p. 204-22, at p. 222; D. G. Boyce, "That Party Politics Should Divide Our Tents: Nationalism, Unionism and the First World War", in Adrian Gregory and Senia Paseta (eds.), Ireland and the Great War "A War to Unite Us All?", Manchester, Manchester University Press, 2002, p. 190-217, at p. 209-11.

3. J. J. Lee, Ireland 1912-1985, Cambridge, Cambridge University Press, 1989, p. 589.

4. The Origins of the First World War: Great Power Rivalry and German War Aims, edited by H. W. Koch, London, Macmillan, 1972, p. 3-12.

5. Mr Punch's History of the Great War, London, New York, Toronto and Melbourne, Cassell, 1919. On soldiers' letters, much recent research is summarised in Neil Jakob, "Representation and Commemoration of the Great War", Irish History: A Research Yearbook, No. 1, Dublin, Four Courts Press, 2002, p. 75-88.

6. War Letters of Fallen Englishmen, London, Victor Gollancz, 1930. The collection also included some letters written by Dominion soldiers and Americans (Jakob, op. cit., p. 78-79).

7. Ian McBride, "Memory and Identity in Modern Ireland", in McBride (ed.), History and Memory in Modern Ireland, p. 1-42, at p. 6-7.

8. Helen Heusner Lojek, Contexts for Frank McGuinness's Drama, Washington, Catholic University of America Press, 2004, p. 67.

9. J.M. Winter, The Experience of World War I, Oxford, Equinox, 1988, p. 92.

10. Paul Fussell, The Great War and Modern Memory, Oxford, Oxford University Press, 1975, p. 35.

11. See, e.g., Robin Prior and Trevor Wilson, "Paul Fussell at War", War in History, Volume I, No. 1, 1994, 63-80.

12. In addition to Winter, op. cit., and Fussell, op. cit., see also Samuel Hynes, A War Imagined: The First World War and English Culture, London, Pimlico, 1992; Jay Winter, Sites of Memory, Sites of Mourning: The Great War in European Cultural History, Cambridge, Cambridge University Press, 1995; Jay Winter and Emmanuel Sivan (eds), War and Remembrance in the Twentieth Century, Cambridge, Cambridge University Press, 1999.

13. Irish Historical Studies, Volume I, No. 1, March 1938, Preface, p. 2; statement under "Writings on Irish History", ibid., p. 68.

14. See e.g., Michael MacDonagh, The Irish at the Front, with an introduction by John Redmond, M.P., London, New York and Toronto, Hodder \& Stoughton, 1916; idem, The Irish on the Somme, with an introduction by John Redmond, M.P., London, New York and Toronto, Hodder \& Stoughton, 1917; Anon., The Great War 1914-1918. Ulster Greets her Brave and Faithful Sons and Remembers her Glorious Dead, Belfast, Bairds, 1919.

15. Cyril Falls, The History of the $36^{\text {th }}$ (Ulster) Division (first published 1922) London, Constable, 1998, p. xv.

16. Ibid., p. 43.

17. It has been estimated that the 36 th Division suffered some 5,000 casualties on 1-2 July, of whom at least 2,000 died. See Philip Orr, The Road to the Somme. Men of the Ulster Division Tell Their Story, Belfast, Blackstaff Press, 1987, p. 199-200; Tom Johnstone, Orange, Green and Khaki: The Story of the Irish Regiments in the Great War 1914-18, Dublin, Gill \& Macmillan, 1992, p. 235. 
18. Falls, op. cit., p. XIII.

19. Ibid., p. XI, 301.

20. Keith Jeffery, Ireland and the Great War, Cambridge, Cambridge University Press, 2000, p. 133-4.

21. As in Britain, however, some socialists took a different view, including the poet John Hewitt, who stressed the futility of the war: see Edna Longley, "The Rising, the Somme and Irish Memory", in Máirín Ní Dhonnchadha and Theo Dorgan (eds), Revising the Rising, Derry, Field Day, 1991, p. 29-49, at p. 40.

22. See, e.g., Hugh Shearman, Anglo-Irish Relations, London, Faber \& Faber, 1948, p. 163; A.

T. Q. Stewart, The Ulster Crisis, London, Faber \& Faber, 1967, p. 242.

23. Henry Harris, The Irish Regiments in the First World War, Cork, Mercier Press, 1968, p. 210.

24. Orr, op. cit., p. 218.

25. Liam de Paor, Divided Ulster, Harmondsworth, Penguin Books, 1971, p. 83.

26. Ibid., p. xx; Constantine Fitzgibbon, Red Hand: The Ulster Colony, London, Michael Joseph, 1971, pp. 333-335.

27. See two works by Ian Adamson, Cruthin: The Ancient Kindred, Newtownards, Pretani Press, 1974, also published as The Cruthin, Belfast, 1986, 1991; The Identity of Ulster: The Land, the Language and the People, Belfast, Pretani Press, 1982, 1991.

28. Personal communication.

29. A. T. Q. Stewart, The Narrow Ground: Patterns of Ulster History, London, Faber \& Faber, 1977 , p. 183-185.

30. OSU, p. 47: all references to Faber edition, London, 1986.

31. Hiroko Mikami, Frank McGuinness and his Theatre of Paradox, Gerrards Cross, Colin Smythe, 2002, p. 15; Lojek, op. cit., p. 77.

32. Fussell, op. cit., ch. 6; cf Falls, op. cit., p. XVI.

33. 33. Fussell, op. cit., ch. 3.

34. The accuracy of Fussell's account of life at the front has been questioned: see Prior and Wilson, op. cit., who ask whether the complexities of modern warfare can be laid bare on the basis simply of literary sources and some personal accounts (p. 63).

35. Recent research on Ireland and the First World War is reviewed in Timothy Bowman, The Irish Regiments and the Great War: Discipline and Morale, Manchester, Manchester University Press, 2003, p. 1-7.

36. David Fitzpatrick, "Militarism in Ireland, 1900-1922", in Thomas Bartlett and Keith Jeffery (eds), A Military History of Ireland, Cambridge, Cambridge University Press, 1996, p. 379-406, at p. 389.

37. Nicholas Perry, "Maintaining Regimental Identity in the Great War: The Case of the Irish Infantry Regiments", Stand To!: The Journal of the Western Front Association, No. 52 (April 1998), p. 5-6.

38. James Loughlin, Ulster Unionism and British National Identity Since 1885, London and New York, Pinter, 1995, p. 82.

39. OSU, p. 54.

40. Fitzpatrick, "Militarism in Ireland", p. 389. 
41. Falls, op. cit., p. 2-5.

42. Fitzpatrick, "Militarism in Ireland", p. 389.

43. Jeffery, Ireland and the Great War, p. 19-20.

44. Fitzpatrick, "Militarism in Ireland", p. 389; see also idem, "The Logic of Collective Sacrifice: Ireland and the British Army, 1914-1918", Historical Journal, Volume 38, No. 4, 1995, 1017-1030, at p. 1023; Loughlin, op. cit., pp. 77-79.

45. See veterans cited by Orr, op. cit., p. 225; also Fitzpatrick, "Militarism in Ireland", p. 389.

46. Fitzpatrick, "Militarism in Ireland", p.379; John Gooch, "Attitudes to War in Late Victorian and Edwardian England", in Brian Boyd and Ian Roy (eds), War and Society: A Yearbook of Military History, London, Croom Helm, n.d., 1975?, 99-100.

47. Fitzpatrick, "Militarism in Ireland", p.381-91; idem, "The Logic of Collective Sacrifice", p.1028-1029. The significance of the links between the U.V.F. and the $36^{\text {th }}$ Division are reassessed by Timothy Bowman, "The Ulster Volunteer Force and the Formation of the $36^{\text {th }}$ (Ulster) Division", Irish Historical Studies, Volume 32, No. 128, Nov. 2001, 498-518.

48. Orr, op. cit., p. 161-4; Falls, op. cit., p. 12.

49. Fitzpatrick, "The Logic of Collective Sacrifice", p. 1029; idem, "Militarism in Ireland", p. 388-389; Bowman, “The Ulster Volunteer Force”, p. 513-4.

50. MacDonagh, The Irish on the Somme, p. 27-28; Myles Dungan, Irish Voices From the Great War, Dublin, Irish Academic Press, 1995, p. 126.

51. Winter, Experience of World War I, p. 114.

52. OSU, p. 62; Bowman, Irish Regiments, p. 202-203.

53. Fussell, op. cit., p. 21-29.

54. Cf Falls, op. cit., p. 61; Johnstone, op. cit., p. 224; Prior and Wilson, op. cit., p. 67-8.

55. Bowman, Irish Regiments, p. 26; Winter, Experience of World War I, p. 146-7. On morale in the British forces during the Great War, see also David Englander and James Osborne, "Jack, Tommy, and Henry Dubb: The Armed Forces and the Working Class", Historical Journal, Volume 21, No. 3, 1978, 594-5.

56. OSU, p. 11.

57. On this subject, see Fussell, op. cit., ch. 8.

58. OSU, p. 62; Winter, Experience of World War I, p. 147.

59. See Prior and Wilson, op. cit., p.67; Jeffery, Ireland and the Great War, p. 9-10; Gary Sheffield, The Somme, London, Cassell, 2003, p. XII-XV.

60. Falls, op. cit., p. 16-17; Orr, op. cit., p. 57-8, 124-6; Perry, "Maintaining Regimental Identity", p. 9.

61. Bowman, Irish Regiments, p. 26-8.

62. OSU, p. 32, 66-67, 78-79.

63. OSU, p. 77-79.

64. Falls, op. cit., p. 63; Orr, op. cit., p. 58, 129-131.

65. Bowman, Irish Regiments, p. 86-87. 
66. Anon., The Great War 1914-1918, p. 20; MacDonagh, Irish on the Somme, p. 24, 36, 39; John Buchan, The Battle of the Somme, Volume 16 of Nelson's History of the War, 24 Volumes, London, Edinburgh, and New York, Thomas Nelson, 1914-1919, p. 41; Falls, op. cit., p. 51.

67. David Officer, “'For God and Ulster': The Ulsterman on the Somme”, in McBride (ed.), History and Memory in Modern Ireland, p. 160-183, at p. 168.

68. Orr, op. cit., p. 164, 170; Dungan, op. cit., p. 126.

69. Orr, op. cit., p. 218.

70. Kevin Myers, "The Irish and the Great War" (programme note, OSU, Abbey Theatre, Dublin, October 1994), and for further discussion see Dungan, op. cit., p. 109.

71. Jeffery, Ireland and the Great War, p. 56; see also Mikami, op. cit., p. 20-21.

72. For a discussion of the issue of "authenticity" in respect of published collections of soldiers' letters, see Jakob, op. cit., p. 75-77; Winter and Sivan, "Setting the Framework", in Winter and Sivan, op. cit., p. 6-39, at p. 13.

73. OSU, p. 9-11.

74. For a valuable discussion of the issue of history and memory in OSU see Klein, op. cit., 105-110.

75. Ian McBride, "Ulster and the British Problem", in Richard English and Graham Walker (eds), Unionism in Modern Ireland: New Perspectives on Politics and Culture, Basingstoke, Macmillan, 1996, p.1-15, at p.6-7. Also of interest is Richard R. Russell, "Ulster Unionism's Mythic and Religious Culture in Observe the Sons of Ulster", Working Papers in Irish Studies, Nova Southeastern University, Fort Lauderdale, Florida, 1998, pp. 1-16.

76. See Johnstone, op. cit.; Terence Denman, Ireland's Unknown Soldiers: The $16^{\text {th }}$ (Irish) Division in the Great War, 1914-1918, Dublin, Irish Academic Press, 1992; Dungan, op. cit.

77. Jeffery, Ireland and the Great War, p. 131-134.

78. Alvin Jackson, Ireland 1798-1998: Politics and War, Oxford, Blackwells, 1999, p. 279, 336-339; Brian Barton, "Northern Ireland, 1920-25", in J. R. Hill (ed.), A New History of Ireland VII: Ireland 1921-1984, Oxford, Oxford University Press, 161-198, at p. 173-198.

79. Jeffery, Ireland and the Great War, p. 123-35.

80. McBride, "Ulster and the British Problem", p. 1.

81. Ibid., p. 12-13; Jackson, op. cit., p. 400-1.

82. OSU, p. 10.

83. OSU, p. 33-4, 38-9, 72-3. See also Jordan, op. cit., p. 39-40.

84. Irish Times, 23 Feb. 1985 (cited in Mikami, op. cit., p. 236-237 (n. 12)).

85. OSU, p. 78.

86. OSU, p. 11.

87. Winter, Sites of Memory, p. 2.

88. Cf Berenice Shrank, "World War I in the Plays of Shaw, O'Casey and McGuinness, Études Irlandaises, Vol. 17, No. 2, December 1992, 29-36 (p. 34).

89. OSU, p. 9-12.

90. Winter, Sites of Memory, p. 5.

91. Ibid., p. 227-228. For the prevalence of such styles of memorials in Ireland see Jane Leonard, "Lest We Forget", in David Fitzpatrick (ed.), Ireland and the First World War, 
Dublin, Trinity History Workshop, 1986, p.59-67; Jeffery, Ireland and the Great War, p. 108-133.

92. Winter, Sites of Memory, p. 228.

\section{ABSTRACTS}

This paper examines the treatment of Ireland and World War One in Observe the Sons of Ulster Marching Towards the Somme, one of Frank McGuinness's best-known plays, and among the leading Irish history plays of the twentieth century. The play has received considerable analysis from literature specialists, but much less from historians. In particular, the paper considers the play in the context of the evolving historiography of the First World War, including Irish participation, history and memory, and forms of commemoration.

Specific issues discussed include who enlisted, and why; why soldiers were prepared to stay and fight (despite the high level of casualties), and Ulster Protestant identity. Among the scholars and writers whose work is mentioned are Tim Bowman, Cyril Falls, David Fitzpatrick, Paul Fussell, Henry Harris, Laurence Housman, Keith Jeffery, Jennifer Johnston, Kevin Myers, David Nowlan, Philip Orr, A.T.Q. Stewart, and Jay Winter.

Cet article analyse la représentation de l'Irlande et de la Première Guerre mondiale dans Observe the Sons of Ulster Marching Towards the Somme, une des pièces les plus connues de Frank McGuinness, et une des pièces historiques irlandaises majeures écrites au xxe siècle. La pièce a déjà fait l'objet d'un nombre considérable d'études de la part de spécialistes de littérature, mais a reçu moins d'attention de la part des historiens. Cet article replace la pièce dans le contexte de l'évolution de l'historiographie de la Première Guerre mondiale, concernant en particulier la participation des Irlandais, le rapport entre histoire et mémoire, et les formes de la commémoration. Les questions précises discutées ici sont : qui étaient ceux qui s'engagèrent, et quelles raisons ils avaient de le faire ; pourquoi les soldats étaient prêts à rester et à se battre, en dépit du grand nombre de tués; et l'identité protestante de l'Ulster. Parmi les spécialistes et auteurs dont le nom est mentionné apparaissent Tim Bowman, Cyril Falls, David Fitzpatrick, Paul Fussell, Henry Harris, Laurence Housman, Keith Jeffery, Jennifer Johnston, Kevin Myers, David Nowlan, Philip Orr, A.T.Q. Stewart, et Jay Winter.

\section{INDEX}

Keywords: battle of the Somme (1916), Easter Rising (1916), First World War, history and fiction, McGuinness Franck, drama, Northern Ireland - conflict, Ulster Division (36th)

Mots-clés: bataille de la Somme (1916), McGuinness Frank, histoire et fiction, Première Guerre mondiale, Irlande du Nord - conflit, théâtre, division d'Ulster (36e), soulèvement de Pâques (1916) 
AUTHOR

JACQUELINE HILL

Department of History, NUI Maynooth 